\title{
Health Risk Behaviors: Smoking, Alcohol, Drugs, and Dating among Youths in Rural Central Java
}

\author{
Zahroh Shaluhiyah*, Syamsulhuda B Musthofa, Ratih Indraswari, Aditya Kusumawati
}

Health Education and Behavioral Sciences, Faculty of Public Health, Diponegoro University, Indonesia

\begin{abstract}
Adolescents are more likely to adopt risky health behaviors, such as smoking, alcohol use, and sexual activity. This study examined the links between smoking, alcohol use, and risky dating behavior and analyzed how these factors influenced risky dating and other behaviors. It is expected that this study would be used as a foundation for developing appropriate integrated intervention for multiple risk behaviors among youths. This study was an explanatory research study with a cross-sectional approach. It involved 160 youths aged 15-24 years randomly selected from purposive villages. Participants completed self-administrated questionnaires with an enumerator present. Data were analyzed using univariate, chi-square, and multiple logistic regression. Smoking behavior, leisure activity, and self-efficacy were predictors of risky dating behavior. The self-efficacy variable also influenced multiple risk behaviors. A strong association was found between smoking, risky dating behavior, and alcohol use. One-third of the participants had dated and smoked recently, but only $10 \%$ of them had experienced high-risk dating activity, including petting and intercourse. Only 5\% had experienced alcohol use (in particular, traditional alcohol), and no one admitted being involved with drug abuse.
\end{abstract}

Keywords: alcohol use, dating behavior, drugs, smoking, youth

\section{Introduction}

Adolescence is a period of rapid physical and psychological growth and development. During this time frame, young people show great curiosity and love for challenging adventures and tend to take risks without considering the consequences. The fact that young people are naturally less control of their emotions makes it easy for them to fall into unhealthy behaviors or lifestyle. ${ }^{1}$

Based on the 2012 Indonesia Demographic and Health Survey data, approximately $33.3 \%$ of girls and $34.5 \%$ of boys aged $15-19$ began dating before the age of 15 . Unwanted pregnancy and sexually transmitted diseases are risks of premarital sexual behaviors among youth. Unwanted pregnancy in young women create the risk of abortion and teenage marriage. Both implicate the future of adolescents' health and their infants. Indonesia has the $37^{\text {th }}$ highest percentage of young marriages. Early marriages are risky because youth are unprepared physically, psychologically, and mentally to build new families. ${ }^{2}$

Youth also often participate in other unhealthy behavior, including smoking, alcohol use, and drug

Correspondence*: Zahroh Shaluhiyah, Health Education and Behavioral Sciences Faculty of Public Health Diponegoro University, Semarang, Indonesia, E-mail: shaluhiyah.zahroh@gmail.com, Phone: +62 811273356 abuse. ${ }^{3}$ In Indonesia, the number of current smokers rose from $7 \%$ in 2015 to $8.8 \%$ in 2016 . Ministry of Health data shows that the prevalence of 15-year-old smokers in Indonesia increased to $36.3 \%$, compared to only $27 \%$ in 1995. ${ }^{4}$ This means that Indonesia is the country with the the most third-hand smoke. Because smoking is allowed everywhere, residual nicotine and other chemicals are left behind on clothing and indoor surfaces, causing a potential threat to family and working environments health. ${ }^{5}$ Many adolescents are familiar with cigarettes from elementary school or even earlier. The number of adolescents who start smoking cigarette in Indonesia is alarming and certainly has impact on health and quality of life for the younger generations. ${ }^{6}$ While, for alcohol consumption among youth, $3.3 \%$ of them start drinking at the age of 10 , mostly traditional alcohol drinks (38.7\%). In Central Java, the proportion in 2018 was higher than in 2017.4

In addition, in 2014, injecting drug use also contributed $7.7 \%$ to the number of human immunodeficiency virus and acquired immune deficiency syndrome (HIV/AIDS) cases in Indonesia. Although this

Received : December 31, 2018

Revised : June 26, 2019

Accepted : July 9, 2019 
figure is lower than in the previous years, it is considered as iceberg phenomenon that needs prevention as early as possible. This is because most AIDS sufferers are infected with HIV when they are still adolescents. ${ }^{7}$

The Indonesian Ministry of Health launched the " $A B A T$ " (I Proud I Know) program in 2013 aimed at preventing HIV/AIDS among adolescents. This program targets youths aged 15-24 years to elevate their knowledge and awareness of HIV/AIDS, particularly how it can be transmitted through unsafe sex and injecting drug use. ${ }^{8}$ The National Population and Family Planning Board or Badan Kependudukan dan Keluarga Berencana Nasional (BKKBN) developed the GenRe (Planning Generation) program for unmarried adolescents aged 10-24 years and families and communities who care about them. This program provides information about reproductive health and the risks of early marriage, premarital sex, and alcohol and drug use. By promoting healthy life skills and adolescents' self-concept, the program hopes to encourage better family planning and future healthy lives. ${ }^{9}$ Unfortunately, this program is considered ineffective because it has not contributed significantly to the reduction of HIV, sexually transmitted infections (STIs), or unwanted pregnancy. The program is also less focused on smoking, alcohol, and drug abuse. Despite the adolescents are the nation's valuable generation, life skill education is provided sporadically and typically only by Non-governmental organizations (NGOs), and some schools through extra-curricularly. ${ }^{10}$

Adolescent sexual and other problematic behaviors such as smoking, alcohol use, and drug abuse share certain common features. Studies in the United Kingdom (UK) and the United States (US) have found associations between substance use and risky sexual behavior among adolescents. ${ }^{11}$ When youths participate in one risky health behavior, they tend to participate in other risky health behavior. ${ }^{12}$ Despite the assumption of an association between smoking, alcohol, and risky sexual behavior, there is limited study targeting youth with multiple risk behavior, particularly in Central Java.

This study examined the factors that influence adolescent risk behavior such as smoking, alcohol use, and dating behavior, and analyzed the interrelationships between smoking, alcohol use, and sexual activity among adolescents in Central Java, Indonesia. This study would provide much needed information to improve the understanding of what shaped sexual risk-taking behavior, and particularly what the role of smoking, alcohol use, and drug abuse contributing to risky dating behavior among the youth.

\section{Method}

This study employed an explanatory research method with a cross-sectional approach. Sample size was calculated using a formula for single proportion, with the $\mathrm{z}$-value corresponding to the confidence of $95 \%$ and the z-score to the power of $80 \%$. The prevalence level for multiple risk behavior was 30\% from previous studies, 13 and the expected prevalence level was $40.5 \%$. A total of 160 randomly-selected adolescents aged 15-24 years were involved in this study. The inclusion criteria were willing to participate and to be involved in the next phase of the study. The Sembukan and Sidorejo Villages of the Wonogiri Subdistrict and the Sukorejo and Sidokumpul Villages of the Demak Subdistrict were selected purposively based on having higher incidences of smokers, alcohol users and adolescent with sexual courtship activity, such as kissing and making out. Married youths were excluded, so contraception use was not assessed in this study.

This study used the type of self-administration in which a structured questionnaire was provided to respondents with an enumerator present. The validated questionnaire consisted of sections covering the respondents' personal background (individual and parent characteristics), religiosity, self-esteem, self-efficacy, social activity, knowledge and attitudes multiple risk behaviors (reproductive health, smoking, alcohol use, and drug use), as well as that of respondents' friends, parents, and other key persons. The questionnaire was developed and adopted from a UK adolescent multiple risk behavior survey, ${ }^{13}$ Rosenberg's self-esteem scale for cross-sectional direct assessment, ${ }^{14}$ and a self-efficacy scale for adolescents. ${ }^{15,16}$ The Rosenberg's self-esteem scale consists of ten statements that measure degree of confidence by asking the respondent to record a number between 0 "cannot do at all" and 10 "highly certain I can do.". For example, "I feel that I am a worthy person, at least on an equal basis with others." While, the selfefficacy scale measures degree of confidence of youth in terms of the ability to prevent risky health behaviors by choosing an answer from "Truly unsure" to "Truly sure", for example, "I am able to resist peer pressure to smoke cigarettes."

The respondents signed informed consent forms before completing the self-administered questionnaires. The study protocol was approved by the Diponegoro University Faculty of Public Health related to the Research Ethics Committee Document No. 053/EC/FKM/2018. Univariate analysis was used on the data to determine the frequency of each variable distribution. Statistical tests using chi-square and logistic regression were conducted to examine the factors' influence on multiple adolescent risk behavior.

\section{Results}

The youths' average age was 16 years old (SD 1.336); most respondents were over $16(71.9 \%)$, and $28.1 \%$ 
were under 16. More than half of respondents were male $(55 \%)$ with high school education level $(70 \%)$. Most $(66.7 \%)$ spent their allowance buying food and school supplies $(23.3 \%)$, while only $16.7 \%$ spent it on entertainment items, such as topping up their mobile phones. Most respondents' fathers' had a high school education $(46.7 \%) ; 20 \%$ had a junior high school education, and $28 \%$ had only elementary school education. While, the average maternal education was very low: $45 \%$ of respondents' mothers only had elementary school education; $26.7 \%$ had junior high school education, and $23.3 \%$ had high school education. Fathers' occupations were mostly informal jobs (40\%); $26.7 \%$ were farmers, and $18 \%$ were civil servants, with an average monthly income of under IDR 2 million. The mothers were mostly housewives $(38.3 \%)$ and farmers $(26.7 \%)$. More than half $(55 \%)$ of them admitted to being religious people. For adolescent leisure activities, $53 \%$ have watched porn videos; $28 \%$ have read pornographic comics; $40 \%$ have ever courted; and only one person ever visited a prostitute.

In term of sexual behavior, $28 \%$ of respondents had dated recently. The average respondent with a boy/girlfriend has dated twice, with the age of first date falling within the range of 14-16 years old, while the youngest to have dated was 10 years old. Dating activities were categorized as low or high risk, in which the low was defined as holding hands and kissing, and high-risk behavior includes necking, petting, and sexual intercourse. One person had sexual intercourse with a prostitute at the age of 15 years. Regarding smoking and alcohol use, $30 \%$ of smokers had been smoking for 10 years; on average, they started smoking at age 12 . More than $30 \%$ of smokers reported being heavy smokers (1 pack/day); $66.7 \%$ of them reported being light smokers $(<1 \mathrm{pack} /$ day). Only $5 \%$ of them have drunk liquor or local alcohol, and only during wedding parties. In the case of drug users, only two people had tried marijuana long before.

More than half of respondents scored high in knowledge on reproductive health, and the effect of smoking and alcohol's on health. Most respondents provided correct answer to items of basic knowledge: in seven out of 10 items of reproductive health knowledge; five out of seven items of smoking effects; five out of six items of alcohol use effects; and four out of five items of drug effects (correct answers were 54.3\%, 51.3\%, $51.2 \%$, and $67 \%$, respectively). However, many respondents provided incorrect answers to questions about reproductive health knowledge (Table 1). In particular, the majority believed that pregnancy would not occur in only in one instance of intercourse $(41.9 \%)$; did not know about symptoms of STIs $(48.0 \%)$; and believed that eating pineapple after sex could prevent pregnancy $(21.3 \%)$. Additionally, some respondents did not know that cigarettes contain harmful chemicals and cause heart and lung diseases (44\%). Half of respondents also misunderstood the effects of alcohol use on physical and psychological health. Nearly all of them were aware of the dangers of drug abuse (Table 1).

In terms of attitudes toward sexual behavior, smoking, alcohol use, and drug use, the majority of respondents indicated permissive attitudes toward sexual behavior $(56.2 \%)$ and smoking behavior $(62.5 \%)$, but

Table 1. Frequency Distribution of Youths' Knowledge of Reproductive Health, Smoking, and Alcohol Use

\begin{tabular}{|c|c|c|c|}
\hline Variable & Category & $\begin{array}{c}\text { Number of Subjects with Incorrect } \\
\text { Answer }(n=160)\end{array}$ & $\%$ \\
\hline \multirow[t]{3}{*}{ Reproductive health } & Pregnancy will not occur in one-time intercourse & 67 & 41.9 \\
\hline & Eating pineapple after sex prevents pregnancy & 34 & 21.3 \\
\hline & Symptoms of sexually transmitted infections (STIs) & 76 & 48.0 \\
\hline Cigarette smoking & Cigarettes contain harmful chemicals & 70 & 44.0 \\
\hline Alcohol use & Effect of alcohol use on psychological health & 87 & 54.4 \\
\hline Drug use & Effect of drug use on health & 20 & 12.5 \\
\hline
\end{tabular}

Table 2. Association between Smoking, Alcohol Use and Dating Behavior among Youths

\begin{tabular}{|c|c|c|c|c|c|c|}
\hline \multirow{3}{*}{ Category } & \multirow{3}{*}{ Variable } & \multicolumn{4}{|c|}{ Dating Behavior } & \multirow{3}{*}{ p-value } \\
\hline & & \multicolumn{2}{|c|}{ Yes } & \multicolumn{2}{|l|}{ No } & \\
\hline & & Frequency & $\%$ & Frequency & $\%$ & \\
\hline \multirow[t]{2}{*}{ Smoking } & Yes & 21 & 44.7 & 26 & 55.3 & \multirow[t]{2}{*}{0.005} \\
\hline & No & 24 & 22.1 & 89 & 77.9 & \\
\hline \multirow[t]{2}{*}{ Alcohol use } & Yes & 4 & 50.0 & 4 & 50.0 & \multirow[t]{2}{*}{0.270} \\
\hline & No & 81 & 53.3 & 71 & 46.7 & \\
\hline
\end{tabular}


only $31.2 \%$ of youths admitted to consuming traditional alcohol and only $12.5 \%$ admitted to using narcotics. While, friends' attitudes showed similar results in terms of sexual behavior, smoking, drinking, and narcotics use.

Table 2 and Table 3 show a strong association between smoking behavior and dating behavior ( $p$-value = 0.005). The percentage of youth who had dated recently had a higher level of smoking behavior $(44.7 \%)$ compared to those who did not smoke $(22.1 \%)$. On the other hand, alcohol use was not significantly associated with risky dating behavior ( $p$-value $=0.270$ ). This is probably because few youths have experience using alcohol. Interestingly, there was a significant association between alcohol use and smoking behavior among youths, with $\mathrm{p}$ value $=0.001$. A higher percentage of youths who had smoked also drank alcohol $(88.9 \%)$ compared to those who don't drink alcohol $(25.8 \%)$.

Table 4 shows that self-efficacy to prevent risky behavior, smoking behavior, and leisure behavior significantly influenced youth dating behavior ( $\mathrm{p}$-value = $0.048,0.005$ and 0.003 , respectively). Currentlysmoking youth were three times more likely to experience risky dating behavior compared to non-smokers $(\mathrm{OR}=$ 3.03). In addition, youth with negative/risky leisure behavior, such as watching pornographic film or comics and visiting prostitute, were more likely to have risky dating behaviors compared to those with positive/nonrisky leisure behavior ( $\mathrm{OR}=3.21)$. Regarding selfefficacy, youth with high self-efficacy rates of for preventing risky behavior were more protected from risky dating behavior compared to those with low selfefficacy. This means that youth with low self-efficacy were more likely to engage in risky dating behavior.

Table 5 shows the result of multivariate analysis of independent variables to multiple risky behaviors as the dependent variable. Multiple risky behaviors refer to smoking, alcohol use, and risky dating behavior variables. The findings showed that only the self-efficacy variable has a strong influence on multiple risk behaviors ( $\mathrm{p}$-value $=0.041 ;$ OR $=0.51)$. This means that youths who have high self-efficacy were more protected from engaging in multiple risk behavior compared to those with low self-efficacy. When risky dating behavior was examined as a dependent variable, three variables influenced risky dating behavior: positive smoking behavior, risky leisure behavior, and low self-efficacy.

\section{Discussion}

Adolescence is a time of transition period between childhood and adulthood. This period covers a range of ages from 8-14; at which adolescents are searching for their identities, showing great curiosity, and loving the

Table 3. The Association between Alcohol Use and Smoking Behavior among Youths

\begin{tabular}{lccccc}
\hline & \multicolumn{4}{c}{ Smoking Behavior } \\
\cline { 2 - 5 } Alcohol Use & \multicolumn{2}{c}{ Yes } & \multirow{2}{*}{ p-value } \\
\cline { 2 - 5 } & Frequency & $\%$ & Frequency & $\%$ & \\
\hline Yes & 8 & 88.9 & 1 & 11.1 & \multirow{2}{*}{0.001} \\
No & 39 & 25.8 & 112 & 74.2 & \\
\cline { 2 - 4 } & & & & &
\end{tabular}

Table 4. The Result of Multivariate Analysis on Variables of Demographic, Knowledge, Attitude, Friends' and Family Attitude, Self-Efficacy, Self-Esteem, Smoking Behavior, Alcohol Use, and Dating Behavior

\begin{tabular}{|c|c|c|c|c|c|c|c|}
\hline \multirow{2}{*}{ Variable } & \multirow{2}{*}{$\beta$} & \multirow{2}{*}{ SE } & \multirow{2}{*}{ Wald } & \multirow{2}{*}{ Sig. } & \multirow{2}{*}{$\operatorname{Exp}(\beta)$} & \multicolumn{2}{|c|}{ 95\% CI } \\
\hline & & & & & & Lower & Upper \\
\hline Self-efficacy (high) & -0.750 & 0.380 & 3.894 & 0.048 & 0.472 & 0.224 & 0.995 \\
\hline Smoking behavior $(+$ smoking $)$ & 1.110 & 0.392 & 8.026 & 0.005 & 3.033 & 1.408 & 6.535 \\
\hline Leisure behavior (risky) & 1.167 & 0.397 & 8.649 & 0.003 & 3.212 & 1.476 & 6.992 \\
\hline
\end{tabular}

Note: $\mathrm{CI}=$ Confidence Interval, $\beta=$ Beta Coefficient; Sig.= Significance; Exp $(\beta)=$ Beta Exponential

Table 5. The Results of Multivariate Analysis on Variables of Demographic, Knowledge, Attitude, Friends' and Family Attitude, Self-Efficacy, Self-Esteem, and Composite Risky Behaviors (Risky Dating Behavior, Smoking Behavior, and Alcohol Use

\begin{tabular}{|c|c|c|c|c|c|c|c|}
\hline \multirow{2}{*}{ Variable } & \multirow{2}{*}{$\beta$} & \multirow{2}{*}{ SE } & \multirow{2}{*}{ Wald } & \multirow{2}{*}{ Sig. } & \multirow{2}{*}{$\operatorname{Exp}(\beta)$} & \multicolumn{2}{|c|}{ 95\% CI } \\
\hline & & & & & & Lower & Upper \\
\hline Self-efficacy (high) & -0.674 & 0.330 & 4.169 & 0.041 & 0.510 & 0.267 & 0.973 \\
\hline Self-esteem (high) & 0.524 & 0.330 & 2.513 & 0.113 & 1.688 & 0.887 & 3.225 \\
\hline
\end{tabular}

Note: $\mathrm{CI}=$ Confidence Interval, $\beta=$ Beta Coefficient; Sig.= Significance; Exp $(\beta)=$ Beta Exponential 
challenge of trying new things. Most of the reasons adolescents involve themselves in risky behavior are because of their curiosity; it often occurs without being planned or forced by peers. This reflects an adolescent's lack of understanding about healthy living and the effects of unhealthy behavior, and the lack of ability to face or prevent risky behavior. 8

This study examined the links between smoking, alcohol use, drug use, and sexual behavior among adolescents in Central Java and studied the factors that influence risky dating and other multiple risk behavior. A strong association was found between smoking and risky dating behavior, and a significant association was found between smoking and alcohol use. These associations were even stronger for adolescents with multiple risky behavior. Risky dating behavior determined and the multiple risky behavior variables were also selected as a dependent variable to examine the factors that influence risky behavior. The results of multivariate analysis show that self-efficacy of preventing risk behavior was a predictor of risky dating behavior as well as of multiple risk behaviors among the youth. Negative/risky leisure behavior and smoking behavior were also identified as predictors of risky dating behavior.

Studies in the United Kingdom show that the youth, particularly young boys, who engage in multiple substance use were more likely to report risky sexual behavior. ${ }^{11}$ Although the number of the youth involved in multiple risky behaviors was small in this study, these results aligned with several studies from other countries showed that concurrent multiple risk behavior is associated with low self-efficacy and low self-esteem, as well as a general propensity toward potential risk-taking that is related to the self-regulation capacity influenced by adolescent brain development. ${ }^{11}$

This study showed that $28 \%$ of adolescent were currently dating; this aligns with the fact that most respondents were still in high school and were very young (the average age was 16). Among dating adolescent, only $10 \%$ admitted to having experienced pre-marital sex. Some youths reported trying to go to prostitutes because of being forced by a friend. Several studies suggested that pre-marital sex behavior is strongly influenced by friends' sexual behavior, religiosity, and attitudes. Adolescents with friends with risky sexual behaviors are eight times more likely to engage in risky sexual behavior compared to those who do not have sexually active friends. ${ }^{16}$ In addition, adolescents with more permissive attitudes to sexuality are four times more likely to engage in risky sexual behavior than adolescents who are less permissive. ${ }^{17}$

In terms of smoking behavior, adolescents become familiar with cigarettes at an early age: generally when they are 11-13 years old. World Health Organization (WHO) data confirms that $30 \%$ of people in the world are smokers. Therefore, it can be said that smoking behavior begins during childhood and adolescence. ${ }^{18}$ This study found that $30 \%$ of respondents have smoked, and one-third of smokers were heavy smokers (more than one pack/day). Then, they began smoking since elementary school. There are many reasons behind adolescent's smoking behavior. According to Lewin, smoking behavior is influenced by both social environment and individuals, that is, smoking behavior is not only caused by internal factors, but it is also influenced by external factors, such as parents, family member, other key persons, and the surrounding environment. ${ }^{19}$ When adolescents experience a psychosocial crisis during their development, they often begin to experiment with smoking. The crisis can be seen in the way they decide to take the risk of smoking. For adolescents, smoking behavior and alcohol use are symbolic behavior. By smoking and drinking alcohol, adolescents are trying to look mature, strong, and brave, and to appeal to the opposite sex and to their peers. ${ }^{20}$

In understanding youth risk behavior, many studies in Indonesia concerned with sexual risk behavior have focused more on the youths knowledge and attitude related to sexual behavior. Such investigations limit understanding of other important factors that are potentially protective such as self-efficacy, self-esteem, and locus of control. ${ }^{21}$ This study showed that variables of demography, knowledge, and attitude did not influence risky dating or multiple risk behaviors. However, the self-efficacy variable has a strong association and influence on risky dating and multiple risk behaviors. The literature suggested that self-efficacy influenced initiating behaviors. ${ }^{15}$ Another study has also demonstrated that the youth with high self-efficacy are generally more effective at facing social environmental demands. ${ }^{20}$

Another study found that self-esteem and self-efficacy were related to academic adjustment. Individuals with low self-esteem and low self-efficacy were characterized by a sense of incompetence in social relationships. ${ }^{21}$ This means that low self-esteem and low self-efficacy have been linked to numerous youth risk behaviors such as smoking, alcohol use, and sexual behavior. Youth engaging in these risky behavior may experience significant health problems in the future. ${ }^{12}$ It is alarming to youth with high self-efficacy while living in the era of increasing lifestyle diseases such as HIV, STIs, heart disease, and cancer. The need to explore how self-efficacy influences multiple risk behaviors is highlighted.

Individual behavior is caused by environmental, personal, and cognitive influences. Multiple risk behavior are not only based on the imitation process and positive 
reinforcement from family and peers, but also in consideration of the consequences of the chosen behavior. ${ }^{15}$ Individuals will find it easier to adopt good behavior if they are supported by family members, friends, and their general social environment. However, this study emphasizes the idea that self-efficacy and selfesteem are possible mediators enabling adolescents to resist negative peer and social environment influences to engage in risky behavior and make informed choices about living healthy lives.

\section{Conclusion}

A strong association was established between smoking and risky dating behavior. Likewise, there is a significant relationship between alcohol use and smoking behavior among youth. Self-efficacy, leisure behavior, and smoking behavior variables are predictors of risky dating behavior, while only self-efficacy is a predictor of multiple risk behavior. This study indicates that youth who never involve with risky behavior have higher selfefficacy. The results highlight the importance of providing youth with the skills they need to feel confident in their ability to avoid health risk behavior like smoking, alcohol use, and sexual behavior.

Only one-third of the youth in this study are currently dating, and $10 \%$ of them participate in high-risk dating activities such as necking, petting, and intercourse. Regarding smoking behavior, $30 \%$ are smokers, although the majority are light smokers (less than one pack/day). This is probably because they are still in school, with no income, thus they smoke only outside school. Regarding alcohol use, only 5\% of respondents have experience with drinking liquor such as beer, wine, and traditional blended alcohol.

In terms of knowledge, nearly half of participants have low levels of knowledge about reproductive health, the effects of cigarette smoking, and alcohol use. Most respondents display permissive attitudes to sexual and smoking behavior, but not toward alcohol or narcotic use. Friends' permissive attitude toward smoking and sexual behavior are also associated with participant's attitudes. This study recommends that youth's life skills are needed to improve self-efficacy and prevent risky behavior as well as to improve knowledge and attitudes by developing interventions aligned with the youth's personal characters, cognitive factors, and socio-cultural environment, particularly before they begin to participate in risky behavior. Further explorative study is needed to study the influence of social-cultural settings, socioeconomic factors, and psychological vulnerability, as well as cognitive factors, including self-efficacy with regard risky behavior, to further policies and interventions.

\section{Abbreviations}

HIV: Human Immunodeficiency Virus; AIDS: Acquired immune deficiency syndrome; ABAT: Aku Bangga Aku Tahu (I Proud I Know); BKKBN: Badan Kependudukan dan Keluarga Berencana; GenRe: Generasi Berencana (Planning Generation) program; STIs: Sexually Transmitted Infections; NGOs: Non-governmental organizations; WHO: World Health Organization.

\section{Ethics Approval and Consent to Participate}

The study protocol was approved by the Diponegoro University Faculty of Public Health related to the Research Ethics Committee Document No. 053/EC/FKM/2018.

\section{Competing Interest}

Author declares that there are no significant competing financial, professional, or personal interests that might have affected the performance or presentation of the work described in this manuscript.

\section{Availability of Data and Materials}

The data that support the findings of this study are available on request from the corresponding author. The data are not publicly available due to containing information that could compromise research participant's privacy/consent.

\section{Authors' Contribution}

Zahroh Shaluhiyah has devised the project, the main conceptual ideas, and proof outline. Syamsulhuda B Musthofa and Ratih Indraswari worked out almost all of the technical details and performed the numerical calculations for the suggested experiment. Aditya Kusumawati supervised the findings of this work. All authors discussed the results and contributed to the final manuscript.

\section{Acknowledgment}

The authors wish to thank the heads of Sembukan and Sidorejo Villages in the Wonogiri Sub-district and Sukorejo and Sidokumpul Villages in the Demak Sub-district, Central Java Province, for allowing the authors conduct this study, including helping our enumerator to collect the data. We would like to extend special thanks to all the respondents for their useful information and cooperation. This work was supported by the Diponegoro University, that the authors thank for financial support.

\section{References}

1. World Health Organization. Scaling up adolescent health in SouthEast Asia report of regional programme managers' meeting. Bangkok; 2011.

2. Statistics Indonesia, National Population and Family Planning Board, Ministry of Health, ICF International. Indonesia demographic and health survey 2012. Jakarta; 2013.

3. Nwagu EN. Alcohol and drug usage; and adolescents' sexual behaviour in Nigeria. Health Promotion International. 2015; 31: 405-13.

4. Kementerian Kesehatan RI. Hasil utama Riskesdas 2018. Jakarta; 2018.

5. Jacob P, Benowitz NL, Destaillats H, Gundel L, Hang B, Green MM, et al. Thirdhand smoke: New evidence, challenges, and future direc- 
tions. 2017; 30(1): 270-94.

6. El Hasna FNA, Cahyo K, Widagdo L. Faktor-faktor yang berhubungan dengan penggunaan rokok elektrik pada perokok pemula di SMA kota Bekasi. Jurnal Kesehatan Masyarakat. 2017; 5(3): 2356-3346.

7. Mardalina A. Faktor-faktor yang berhubungan dengan perilaku seks berisiko HIV/AIDS pada Tenaga Kerja Bongkar Muat (TKBM) di pelabuhan Tanjung Emas Semarang. Jurnal Kesehatan Masyarakat. 2017; 3(3): 869-76.

8. Kementerian Kesehatan RI. Buku petunjuk penggunaan media KIE versi pelajar tentang aku bangga aku tahu. Jakarta; 2012.

9. Susanti HA. Strategi komunikasi Badan Kependudukan dan Keluaga Berencana Nasional (BKKBN). Jurnal Asosiasi Pendidikan Tinggi Ilmu Komunikasi. 2015; 2(4): 243-54.

10. Sekarpuri AD. Inklusi saluran informasi kesehatan reproduksi remaja. Jurnal Studi Pemuda. 2014; 3(2): 133-9.

11. Khadr SN, Jones KG, Mann S, Hale DR, Johnson AM, Viner RM, et al. Investigating the relationship between substance use and sexual behaviour in young people in Britain: findings from a national probability survey. BMJ Open. 2016; 6(6): 1-11.

12. Sychareun V, Thomsen S, Faxelid E. Concurrent multiple health risk behaviors among adolescents in Luangnamtha province, Lao PDR. BMC Public Health. 2011; 11(1): 36.

13. Kipping RR, Smith M, Heron J, Hickman M, Campbell R. Multiple risk behavior in adolescence and socio-economic status: Findings from a UK birth cohort. European Journal of Public Health. 2015; 25(1):
44-9.

14. Altmann T, Roth M. The self-esteem stability scale (SESS) for crosssectional direct assessment of self-esteem stability. Frontiers in Psychology. 2018; 9: 1-9.

15. Tsang SKM, Hui EKP, Law BCM. Self-efficacy as a positive youth development construct : a conceptual review. The Scientific World Journal; 2012.

16. Gloppen KM, H MP, David-ferdon C, Ph D, Bates J, H MP. Confidence as a predictor of sexual and reproductive health outcomes for youth. Journal of Adolescent Health. 2010; 46(3): 42-58.

17. Azinar M. Perilaku seksual pranikah berisiko terhadap kehamilan tidak dinginkan. Jurnal Kesehatan Masyarakat. 2013; 8(2): 153-60.

18. Shaluhiyah Z, Suryoputro A, Setyawati A. The needs of information services on reproductive health, STIs in HIV in middle adolescence. KEMAS: Jurnal Kesehatan Masyarakat. 2017; 12(2).

19. Moghaddam HT, Bahreini A, Abbasi MA. Adolescence health : the needs, problems and attention. International Journal of Pediatri. 2016; 4(26): 1423-38.

20. Perez A de M, Benseñor IM. Tobacco and alcohol use, sexual behavior and common mental disorders among military students at the police academy, São Paulo, Brazil. A cross-sectional study. Sao Paulo Medical Journal. 2015; 133(3): 235-44.

21. Fauzi R, Areesantichai C. Factors associated with cigarettes use among high school students in Jakarta. Kes Mas: Jurnal Kesehatan Masyarakat Universitas Ahmad Daulan. 2016; 10(2): 131-8. 